\title{
Beyond Agency Theory: Value Creation and the Role of Cognition in the Relationship between Entrepreneurs and Venture Capitalists*
}

Peter Wirtz (January 26 2010)

Forthcoming in Rassoul Yazdipour, Advances in Entrepreneurial Finance, Springer, 2010

\begin{abstract}
This chapter explores entrepreneur-investor relations from a cognitive perspective. I show that entrepreneurs' and investors' specific mindsets matter for the perception and realization of strategic opportunity. Differences in cognitive structure and process thus influence value creation beyond economizing on agency costs. I define and add concepts of cognitive cost and cognitive value to a basic agency model, which allows me to explain why some entrepreneurinvestor relations create more value than others, although they may have the same level of agency costs. This enhanced framework also helps understand why external funding may not be available to certain ventures, even if agency conflicts can be kept under control through proper incentive alignment. The concepts of cognitive cost and value are shown to be especially relevant in the context of entrepreneurial finance, where uncertainty is typically high, and knowledge about value creation opportunities is ambiguous. An investor's appreciation of the value of entrepreneurs' knowledge about strategic opportunity depends on the closeness of their respective mindsets. Some investor-types such as venture capitalists share certain of the entrepreneurs' mental features and develop specific skills to identify valuable ventures at a low cognitive cost while adding cognitive value through strategic advice and mentoring, especially when entrepreneurs are still unexperienced.
\end{abstract}

\section{Introduction}

For many years finance scholars have examined the relationship between founder/managers and external investors within the agency framework (Jensen and Meckling, 1976), where information asymmetry and conflicting interests between entrepreneurs and external shareholders lead to agency costs. Under such theory agency costs may be controlled by putting in place the appropriate monitoring and incentive mechanisms to to better align the

\footnotetext{
* I am indebted to Rassoul Yazdipour for helpful comments on an earlier version of this chapter.
} 
entrepreneur's behaviour with investors' interests. Hence, the retention of a significant ownership stake by the entrepreneur may reduce the risk of consuming perquisites and of expending low managerial effort (Jensen and Meckling, 1976; Bitler et al., 2006). Moreover, according to the agency literature, the identity of the external shareholder matters too in as much as certain investor types may have developed superior monitoring and incentive mechanisms to reduce agency costs and hence contribute to value creation. This is supposedly the case of private equity firms (Baker and Wruck, 1989; Jensen, 1993). Consequently, beyond the degree of ownership concentration, investor-type seems to matter when controlling for agency costs in funding entrepreneurial ventures.

Among all sorts of investor-types, venture capitalists are an especially important source of finance for funding young entrepreneurial firms. Empirical studies on the relationship between venture capitalists (VCs) and entrepreneurs, while describing the existence of specific monitoring mechanisms helping to minimize the downside risk on value due to agency conflicts, also document a more direct contribution of these professional shareholders to a firm's upside potential (Cumming and Johan, 2007), and hence to venture success. This added service potentially comes at two levels: (1) the identification or conception of a proper strategy where VCs may act as a sounding board in the strategy formulation process (Rosenstein et al., 1993) and (2) the professionalization of managerial capabilities (Hellman and Puri, 2002). Hence, the contribution of VCs goes beyond the supply of funding and objective financial discipline through monitoring and incentives to include some more specifically cognitive resources, such as new strategic ideas, knowledge and skills. Strategy formulation and skill acquisition imply cognitive structures and processes that are more complex than the mere transfer of objective information through monitoring mechanisms to overcome information asymmetry as traditionally prescribed by agency theory.

In this chapter, we propose an extended conceptual framework of entrepreneur-VC relationship which integrates both agency costs and cognitive costs derived from the strategy literature $^{1}$ and the dynamic capabilities approach ${ }^{2}$ to better understand the overall impact of venture financing on value creation. Integrating cognitive cost and value into an extended agency framework thus may help resolve some potential problems for both entrepreneurs and investors. One important implication is a better understanding of the reasons for which certain VC-entrepreneur relationships are more successful than others, even in cases where agency costs are relatively low. In fact, our framework makes predictions on venture success based

\footnotetext{
${ }^{1}$ Penrose, 1959 ; Barney, 1986; Wernerfelt, 1984.

${ }^{2}$ Teece, Pisano and Shuen, 1997.
} 
on the respective cognitive attributes of $\mathrm{VC}$ firms and entrepreneurs. These predictions are consistent with Gompers et al. (2006), who empirically study the impact of matching different levels of VC skills with different levels of entrepreneurs' skills on venture success. They find that a skilled VC contributes significant (cognitive) value only where the entrepreneur's prior experience in starting a venture is either low or has been a failure. In the latter case, skilled VCs can identify more easily than unskilled VCs the promising entrepreneurs, in spite of the latter's prior failures or lack of experience and help them acquire enhanced management skills.

The first section of this chapter explains why traditional agency theory stops short of explaining the value-creation potential inherent in VC-entrepreneur relationships. Section 2 then proposes a general framework of investor-entrepreneur relationships, emphasizing the potential cognitive role played by certain investor types. Section three applies such framework to the specific case of young entrepreneurial firms funded by venture capitalists, yielding some empirical implications.

1. Entrepreneurial ventures and value creation in an agency setting

Jensen and Meckling (1976) made the seminal contribution to positive agency theory which has become the dominant theoretical framework for analyzing shareholder-manager relationship and its impact on the financial performance of the firm. The starting point in Jensen and Meckling's analysis is an entrepreneurial firm, where the founder is the shareholder and the manager at the same time. In this situation, agency conflicts are absent, because the entrepreneur completely internalizes the value impact of his decisions. Things change when the entrepreneur sells outside equity because such a scenario creates an incentive for the founder/manager to pursue his personal interests to the detriment of the new shareholders. Consequently, when a new shareholder enters, agency costs arise. Such an increase can however be reduced by putting in place the appropriate monitoring and incentive mechanisms.

The question arises, however, why the entrepreneur should open up his venture to investors in the first place since this brings about agency costs which will be anticipated and priced by the potential external shareholders anyway. Jensen and Meckling's answer is in the recognition of the entrepreneur's personal budget constraint. That is to say that the sale of outside equity may be the only means to capture certain value enhancing investment opportunities, simply by loosening the firm's budget constraint. Thus, outside equity brings the firm on a value 
enhancing "expansion path", as long as the incremental value generated from expansion exceeds the marginal agency costs induced by the decrease of the entrepreneur's ownership stake. Consequently, in the Jensen and Meckling model, the possibility to create value through a relationship between the entrepreneur and external shareholders (e.g. venture capitalists) depends on the relative amount of the value supplement inherent in a new investment project and the added agency costs due to the more diffuse ownership structure. Leaning on the ownership structure model initially developed by Roe (2002) and extended by Charreaux (2002), we can note that selling an ownership stake to an outside shareholder creates value, as long as

$\mathrm{V}_{\mathrm{d}}-\mathrm{A}_{\mathrm{mi}}>0$,

where $V_{d}$ is the value created as a result of expanded investment opportunity and when the budget constraint is loosened by bringing in new investors. $\mathrm{A}_{\mathrm{mi}}$ is agency cost in a traditional sense, which has its root causes in the entrepreneur-manager's pursuit of his personal interests under conditions of asymmetric information (perks, leisure, overinvestment). Consequently, the value created by an external shareholder, say a private equity firm, stems from the funds it contributes and its capacity of controlling managerial agency costs by devising the appropriate incentive and control mechanisms. In discussing the O.M. Scott LBO for instance, Baker and Wruck (1989) make a case for the private equity firm's ability to design governance mechanisms (remuneration design, management participation, board of director functioning, covenants) which help decrease agency costs. According to traditional agency theory, value can hence be created in entrepreneur-investor relationships by widening the $V_{d}$ $\mathrm{A}_{\mathrm{mi}}$ spread. It should however be noted that, in the initial agency model, the outside shareholders play no role in constructing the investment opportunity set itself. The latter is given, and the role of outside shareholders is restricted to bringing in financial capital and to supporting the residual risk, while controlling the objective attributes of their investments by maintaining transparency on information flows. In such a model, outside shareholders' impact on the performance of the firm is restricted to the amount of financial capital they put on the table and to their monitoring skills.

2. Cognitive cost and cognitive value inherent in entrepreneur-investor relations

Agency theory focuses on controlling costs of conflicting interests when information is asymmetrically distributed. Value can hence be created by crafting the appropriate monitoring and incentive mechanisms to eliminate such costs. Monitoring reduces information 
asymmetry, whereas incentives align the entrepreneur's interests with those of external shareholders. Jensen (1993) considers the governance mechanisms developed by certain private equity firms as especially efficacious when it comes to economizing on agency costs. Though this may be one important explanation for the success of certain ventures, in many cases, the success of entrepreneurial ventures is not due to financial incentives and monitoring alone. In fact, one major shortcoming of agency theory lies in its implicit assumptions about the origin and the recognition of opportunities to create value. The origin of strategic opportunities and the recognition of their value creation potential are actually exogenous to the theory, and it is simply assumed that good (positive NPV) and bad (negative NPV) projects somehow exist. They are given by the environment, and to maximize value, it is important to have access to information about the good projects, to give incentives to the entrepreneur to choose the good ones and to make him expend optimal effort.

The strategic management literature however has a longstanding tradition in recognizing that making a competitive strategy is as much about cognition (Hambrick and Mason, 1984; Huff, 1990; Walsh, 1995), vision (Fransman, 1994; Witt, 1998), and difficult to imitate capabilities (Penrose, 1959; Teece, Pisano, Shuen, 1997), as it is about mere information. What an entrepreneur perceives as the best strategy depends on her specific mindset. The same goes for an investor. Mindsets are influenced by individual and collective learning processes, which may be highly specific and path dependent. Part of such learning is tacit in nature and thus difficult to communicate to others. One implication of the cognitive nature of strategy formulation is the fact that many value creation opportunities do not exists independently of the people who conceive them in specific organizational contexts. The art of strategy is not simply about choosing the objectively best strategy in a predefined menu. Strategy is created in processes of individual and organizational learning (Nonaka and al., 2001), which rely on capabilities that go beyond the control of conflicting interests.

Fransman (1994) illustrates the central importance of knowledge in creating and realizing the potential of corporate success. He actually draws a clear distinction between information, as it is present in agency theory, and knowledge, as employed in strategic management and evolutionary economics (Nelson and Winter, 1982). Information is in fact defined as objective data about states of the world and state-contingent outcomes. As such, it is a closed set. It may be asymmetrically distributed, but its transfer from one stakeholder to another is possible, albeit at a cost (monitoring costs). In such a context, an information's meaning is unambiguous. Things change when the precise meaning of any given information depends on peoples' mindsets. Thus, even if knowledge evolves with the acquisition of information, there 
is "loose coupling" between the two concepts, which is to say that the interpretation of any piece of information in terms of value creation is not self evident but depends on people's mental patterns at the time they receive the information. The latter may then have an impact on mental patterns and belief structures, but these change in a highly path-dependent way, so that the knowledge gained from new information is sometimes very different from one person to another. In fact, Fransman defines knowledge as dynamic mental constructs. So, in comparison to agency theory's conception of information, knowledge is an open set. It is created in an ongoing learning process, part of which is tacit (Nonaka and al., 2001).

Beyond their privileged access to information in the above defined sense, top managers' specific knowledge structures can hence be crucial in an effort to create value. In their work on upper echelons, Hambrick and Mason (1984) actually consider a firm's strategy to be a reflection of its top managers' cognitive base and values. Since there is only loose coupling between objective information and knowledge gained, some people perceive opportunities for value creation and others do not, even if information is distributed symmetrically. In such a situation, monitoring and incentive alignment alone are insufficient to increase a firm's value. This is because information from the environment is perceived through the lens of an entrepreneur's specific mindset. The latter influences strategy formulation and, ultimately, a firm's performance (Hambrick and Mason, 1984).

One important implication is that there may be a conflict between an entrepreneur and his firm's investors about the best strategy to follow, independently of any problem of conflicting interests. As Conner and Prahalad (1996) put it: “[...] truthful individuals honestly may disagree about the best present and future course of action for their business activities. Or, the parties may possess different mindsets generally. Discord fundamentally derives from personal knowledge that cannot be communicated fully to others at the time of the disagreement." (p. 483). Consequently, our understanding of entrepreneur-investor relations may gain from admitting the existence of cognitive (or knowledge) asymmetry, which is different in nature from mere information asymmetry.

Such cognitive asymmetry is likely to induce conflicts due to mutual misunderstanding among stakeholders (e.g. the entrepreneur and certain external shareholders). Such conflicts are not rooted in mutually inconsistent interests and thus cannot be tackled by the means of interest alignment alone, as traditional agency theory would have it. Their resolution depends on stakeholders' initial skills and knowledge, as well as on their willingness and capability to learn. Thus cognitive conflicts cause costs which may be labelled as cognitive costs. 
The costs stemming from cognitive conflicts are different in nature from costs rooted in agency conflicts. They are related to the various efforts undertaken by stakeholders to overcome differences in the perception of opportunities, to convince others of the relevancy of their conceptions (e.g. an innovative business model), as well as to eventual losses of efficiency due to lasting differences in understanding. The following exhibit sketches out different types of potential cognitive costs in comparison with the traditional agency costs.

Exhibit 1 - Agency costs and cognitive costs in entrepreneur-stakeholder relations

\begin{tabular}{|c|c|}
\hline Agency costs (Jensen and Meckling, 1976) & Cognitive costs \\
\hline $\begin{array}{l}\text { Monitoring aims at reducing information } \\
\text { asymmetry (e.g. through a well informed independent } \\
\text { board of directors). }\end{array}$ & $\begin{array}{l}\text { Mentoring efforts undertaken by certain } \\
\text { stakeholders, such as venture capitalists, may } \\
\text { influence an entrepreneur's mindset and enable him to } \\
\text { engage in relationships with different stakeholder } \\
\text { groups (e.g. financial investors). }\end{array}$ \\
\hline $\begin{array}{l}\text { Bonding is the activity whereby managers convey } \\
\text { credible (and thus costly) signals that they will behave } \\
\text { in accordance with external shareholders' interests. }\end{array}$ & $\begin{array}{l}\text { Externalizing tacit knowledge (Nonaka et al., 2001) } \\
\text { consists of an entrepreneur's efforts to transform his } \\
\text { tacit knowledge into explicit knowledge which can be } \\
\text { communicated to external stakeholders, such as } \\
\text { potential investors. The costs of externalization are } \\
\text { different from bonding costs. The latter's role is to } \\
\text { convince shareholders that the manager's interests are } \\
\text { aligned with shareholder interests, whereas } \\
\text { externalization of partially tacit mindset is aimed at } \\
\text { convincing (potential) stakeholders of the intrinsic } \\
\text { quality of strategic projects. }\end{array}$ \\
\hline $\begin{array}{l}\text { Residual loss is due to the fact that information } \\
\text { asymmetry can never be completely eliminated and } \\
\text { that interest alignment is never perfect. }\end{array}$ & $\begin{array}{l}\text { Cognitive heterogeneity persists because } \\
\text { mindsets are specific and path-dependent and, thus, } \\
\text { never perfectly aligned, in spite of mutual interaction. } \\
\text { Thus, some degree of mutual misunderstanding may } \\
\text { always persist. }\end{array}$ \\
\hline
\end{tabular}

The above presentation of cognitive costs characterizing the relationship between entrepreneurs and external stakeholders, such as venture capitalists, shows that these costs are linked to learning processes that potentially lead to a transformation of strategic knowledge (which may reduce the gap between different mindsets) and to an acquisition of new managerial capabilities. It is however important to emphasize that cognitive conflict differs from traditional agency conflict in a fundamental way. In fact, agency conflict is always value 
reducing, and as long as the marginal cost of monitoring and bonding remains inferior to the marginal reduction in residual losses, the latter's minimization will maximize value. Not so with cognitive heterogeneity, which can actually be value enhancing (Forbes and Milliken, 1999; Hambrick et al., 1996), in as much as it opens up new strategic perspectives and allows to sustain an ongoing process of learning and innovation. Consequently, the specific mindsets of external stakeholders, different from the entrepreneur's own, not only generate cognitive cost, but may also contribute cognitive value by bringing in new perspectives and valuable experience.

Recognizing that certain shareholder types play more roles than just assuming risk Charreaux (2002) proposes an extension of Roe's model of ownership structure by introducing two concepts derived from the above mentioned literature on knowledge and capabilities in strategic management. He does so by adding cognitive cost $A_{c}$ and cognitive value $V_{c}$ to the basic agency model. This is to recognize that certain shareholder types may contribute specific knowledge in the process of strategy formulation. For example, a venture capitalist can act as a sounding board to the entrepreneur who proposes different strategic initiatives. He may also help the firm acquire enhanced management skills (e.g. management control, human resource management ...), which is a manifestation of mentoring. On the other hand, an external shareholder's acquisition of a significant ownership stake may raise costs due to cognitive conflict $A_{c}$. The closer the entrepreneur's cognitive base to a specific investor's mindset, due to common educational background or shared professional experience, the lower the degree of cognitive cost should be.

Hence, the entry of a new shareholder creates value if $V_{d}+V_{c}-A_{m i}-A_{c}>0$, that is value created through loosening the budget constraint and knowledge/skill added by new shareholders exceeds the sum of managerial agency cost and cognitive cost. This can help explain the breakdown of certain agency relationships, even in situations where managerial agency costs are $l_{0}{ }^{3}$. In fact, traditional agency theory would always predict an ownership structure to be viable, as long as $\mathrm{V}_{\mathrm{d}}>\mathrm{A}_{\mathrm{mi}}$, which is the case when the entrepreneur keeps a significant ownership stake (Bitler et al., 2006). However, our discussion of knowledge asymmetry shows that certain potentially value creating ventures

\footnotetext{
${ }^{3}$ This is when an entrepreneur is isolated in his perception of a unique business opportunity for the realization of which he needs external funding. Hence for value to be created the venture needs funds, but financial investors just do not get the point, even though they may have ways to achieve interest alignment (by acquiring only a minority stake, imposing incentive contracts ...). So in spite of agency costs being absent or very low, investors do not enter the venture because $V_{d}$ actually exists in the entrepreneur's perception only. This situation is captured by the model through prohivitive cognitive costs. This means that because of inconsistent mindsets, $\mathrm{A}_{\mathrm{c}}$ simply offsets $\mathrm{V}_{\mathrm{d}}$. Giving an investor access to the entrepreneur's perception of opportunities would translate into the model by lowering $\mathrm{A}_{c}$.
} 
may never have access to external finance, although $V_{d}>A_{m i}$ through proper incentive alignment, because cognitive cost is excessively high. Achieving low cognitive cost likely depends on the relative closeness of entrepreneurs' and shareholders' cognitive structure and ways of reasoning. In other words, when incentives are properly aligned, entrepreneurs should have less difficulty in raising external finance when addressing investors with mental patterns close to their own, due to shared educational background and/or professional experience. In addition, even if incentives are properly aligned through high ownership concentration and monitoring $\left(\mathrm{A}_{\mathrm{mi}}\right.$ low) and if mental patterns are relatively close $\left(\mathrm{A}_{\mathrm{c}}\right.$ low), there still may be significant differences in firm performance due to investor relations, because all shareholders do not necessarily make the same contribution to cognitive value $\left(\mathrm{V}_{\mathrm{c}}\right)$, where different mentoring skills may imply different degrees of venture professionnalization ${ }^{4}$.

\section{Conditions of value creation in entrepreneur-VC relationships}

Cognitive structures and processes should be particularly relevant in the context of entrepreneurship. In fact, according to Krueger (2003, p. 105), "understanding entrepreneurial cognition is imperative to understanding the essence of entrepreneurship, how it emerges and evolves. This is especially true if we wish to move from descriptive research to theory-driven research." Our understanding is that this argument made for entrepreneurship in general applies to entrepreneurial finance likewise. Forbes (1999) advances two arguments in support of the idea that the understanding of cognitive structures and processes should be crucial in coming to grips with the dynamics of entrepreneurial ventures. First, entrepreneurship typically takes place in a context of high uncertainty, where resource-output-performance relations are very ambiguous. In such a setting, special cognitive features may be required to take effective action, such as the use of specific heuristics (Alvarez and Busenitz, 2001; Busentiz and Barney, 1997) and non linear processes of reasoning. Entrepreneurial cognition, thus different in nature from cognition of managers in large established firms, may be a key to understanding why entrepreneurs perceive opportunities where others see nothing. Beyond the entrepreneur's own perception, the capacity of representing the perceived opportunities to stakeholders is also crucial in the effort to assemble the strategic resources to realize the venture (Barney, 1986; Forbes, 1999). The latter aspect, however, has received less attention in the literature on managerial cognition. The present chapter can be seen as a tentative

\footnotetext{
${ }^{4} \mathrm{~V}_{\mathrm{c}}$ is the specific cognitive input made by the investor: new ideas, more professional managerial capabilities ...
} 
contribution to bridge this gap, in as much as our concept of cognitive cost relates to the learning effort necessary to obtain shared representations of opportunities by entrepreneurs and key stakeholders such as potential contributors of equity finance.

Secondly, the relatively small size of new ventures gives special significance to the entrepreneur's specific mindset, probably more so than in the typical large managerial firm. "The implication of individual-level and group-level cognition [...] may be more direct and immediate in the context of new venture creation than is the case in more conventional organizational settings. Most new ventures have only one or a few key managers at their core [...] Thus their beliefs and decision-making processes are likely to be more concentrated than those of large organizations." (Forbes, 1999). Because of this concentration, the potential of cognitive conflict may be especially strong in young entrepreneurial ventures, with the inexperienced entrepreneur often being isolated and having a hard time communicating his original strategic ideas to investors from a different background than his own. The early stage in a firm's lifecycle can thus be considered to be a particularly appropriate setting to study the concepts of cognitive cost and value in an extended model of agency relationships.

The cognitive dimension of the investor-entrepreneur relationship may be especially important at an early stage in a firm's lifecycle, when an entrepreneur's managerial experience is low. In this case, the entrepreneur's perception of strategic opportunities is likely to depend significantly on tacit (hard to communicate) knowledge. The latter may be an outcome of non linear processes of heuristic-based reasoning, which Busenitz and Barney (1997) consider to be a typical feature of entrepreneurs' cognitive process. An investor's ability to ascertain the strategic value of knowledge gained from such process is likely to depend on his own specific knowledge and on his ability to penetrate the entrepreneur's specific mode of reasoning. Cognitive conflict between entrepreneurs and certain investor categories is thus potentially strong, if the latter lack the requisite mental skills and training. For example, traders at large institutional investors (IIs) are trained to make investment decisions based on the assumptions of rationality implicit in traditional financial economics. This very analytical approach to decision making may thus be at a great distance from the typical entrepreneur's approach to decide on strategic opportunities. Consequently traditional investors are likely to have a hard time in appreciating the value creation potential of entrepreneurial ventures. Monitoring skills developed to control conflict of interests (source of traditional agency costs) are not of any help in this matter, because they suppose that good (positive NPV) and bad (negative NPV) investment projects can easily be distinguished by the investor. Where they can't, even though $V_{d}$ as perceived by the entrepreneur may be 
potentially high, the traditional large institutional investor whose perception of strategic opportunity is at a long distance from the entrepreneur's will not fund the venture, even when $\mathrm{A}_{\mathrm{mi}}$ (traditional agency costs) are low. The reason is the strong effort necessary to engage in learning which would ultimately improve mutual understanding. It would simply be too time consuming and too costly in relation to the financial stake. In such a situation, $A_{c}$ (the cognitive cost due to a lack of mutual understanding) is very high, whereas $\mathrm{V}_{\mathrm{c}}$ (the specific cognitive value this investor is able to bring to the venture) is typically low, so that $V_{d}+V_{c}$ II $<\mathrm{A}_{\mathrm{mi}}{ }^{\mathrm{II}}+\mathrm{A}_{\mathrm{c}}{ }_{\mathrm{c}}$. . This relationship is thus not viable, the prime cause not being prohibitive agency costs, but a cognitive mismatch between entrepreneurs and those investors which invest at arm's length.

Those young firms where a strong competitive advantage crucially hinges on tacit knowledge derived from entrepreneurs' personal experience and heuristic-based reasoning may thus have few possibilities to raise external finance, even if one could effectively control for problems of interest alignment and information asymmetry in a traditional sense $\left(\mathrm{A}_{\mathrm{mi}}\right)$. Rather than mere information asymmetry, these firms face problems inherent in cognitive asymmetry. Monitoring is insufficient to overcome the latter because of the loose coupling between information and knowledge (Fransman, 1994). As a matter of consequence, arm's length finance is not available, because tacit knowledge cannot be readily traded at arm's length (Forbes, 1999). The sharing of tacit knowledge requires specific mental skills and a certain learning effort.

Certain investors, however, such as venture capitalists and business angels, may possess or develop these specific cognitive skills that allow them to enter into a relationship with an entrepreneur at a low cognitive cost. Those are investors capable of recognizing the potential of promising young ventures, because they are able to cope with entrepreneurial cognition. If the entrepreneur lacks managerial experience, these investors may not only enter at a low cognitive cost $\left(\mathrm{A}_{\mathrm{c}}\right)$, but also have a strong potential cognitive input $\left(\mathrm{V}_{\mathrm{c}}\right)$. This is the case, for example, when venture capitalists (VCs) play a strong role in professionalizing managerial functions in young ventures (Hellmann and Puri, 2002). Hence, the inequality becomes $\mathrm{V}_{\mathrm{d}}+\mathrm{V}_{\mathrm{c}}^{\mathrm{VC}}>\mathrm{A}_{\mathrm{mi}}+\mathrm{A}_{\mathrm{c}}^{\mathrm{VC}}$.

One testable implication is that venture capitalists should typically be expected to invest where the entrepreneurs' cognition is close to their own. In fact, closeness of mental patterns and cognitive process reduces cognitive cost. This theoretical prediction is consistent with empirical evidence, according to which venture capitalists prefer to invest when there is a certain degree of cognitive similarity with the entrepreneur (Murneiks et al., 2007). 
The management literature on strategic resources, managerial capabilities and learning, however, teaches us that knowledge structures and skills are not static but change as a result of dynamic path dependent processes. This implies that the concepts of cognitive cost and value are themselves dynamic and time dependent. As a venture matures, the inherent value creation potential becomes more explicit, and even shareholders without the specific cognitive skills of VCs and business angels may see an interest in contributing financial capital to further growth. The firm may then be taken public without arm's length investors facing special problems of cognitive cost any more.

The entrepreneur's own cognitive structure may also evolve due to the accumulation of experience with the maturing venture and due to certain shareholders' mentoring efforts. Consequently, the potential to create cognitive value $\left(\mathrm{V}_{\mathrm{c}}\right)$ should be higher with inexperienced entrepreneurs than with serial entrepreneurs, which is consistent with empirical evidence from Gompers et al. (2006). The latter actually show that experienced VCs have higher success rates than their less experienced competitors, only in cases where the venture is started by a first-time entrepreneur. With serial entrepreneurs, success rates are not significantly different between high-experience and low-experience VCs. This is consistent with our model in as much as it can be supposed that the success of serial entrepreneurs is a positive signal with respect to the quality of their entrepreneurial capabilities, which can be readily observed by almost any professional investor. Such a signal hence decreases potential cognitive cost on a wide scale. Not so with first-time entrepreneurs. In the latter case, the fit between the entrepreneurs' and the VCs' cognition should be particularly relevant in achieving low cognitive cost. That is because their long experience of interacting with entrepreneurs (some of them first-time) likely helps established VCs develop an intimate understanding of successful entrepreneurs' cognitive structure and process. Hence, it can be supposed that experienced VCs have developed specific mindsets which help them track the existence of potentially value creating tacit knowledge, even in the absence of an explicit track record. So, in comparison with their inexperienced counterparts, the better VCs experience lower cognitive cost when choosing to invest alongside entrepreneurs without a track record. It is also in such a situation that potential cognitive value from mentoring can be supposed to be highest, whereas serial entrepreneurs are likely to have already acquired such value through the experience with their previous ventures. 
Conclusion

This conceptual chapter has set out to demonstrate that entrepreneurial finance may gain explanatory power with respect to entrepreneur-investor relations, by integrating the concepts of cognitive cost and value derived from the management literature in an extended model of agency. In fact, issues of cognition have been shown to be particularly relevant in the context of entrepreneurship (Alvarez and Busenitz, 2001;Busenitz and Barney, 1997; Forbes, 1999; Krueger, 2003). Our model predicts that arm's length financing is not an option for most entrepreneurs, even if there was a check on agency costs due to sound monitoring and interest alignment mechanisms, because the average arm's length investor faces high cognitive cost ${ }^{5}$ while contributing low cognitive value ${ }^{6}$. In fact, potential shareholders' identity matters, in as much as it determines their cognitive structure and process. The latter have an impact on cognitive value added and cognitive cost, due to more or less inconsistent mindsets. We have shown that the traditional instruments of value optimization derived from agency theory (interest alignment and transparent monitoring) are insufficient to fully exploit the value potential to be gained from entrepreneurial cognition.

\section{References}

Alvarez, S. and Busenitz, L. (2001), 'The Entrepreneurship of Resource Based Theory', Journal of Management, 27: 755-775.

Baker, G. P. and Wruck, K. H. (1989) 'Organizational Changes and Value Creation in Leveraged Buyouts: The Case of the O. M. Scott \& Sons Company', Journal of Financial Economics 25: 163-190.

Barney, J.B. (1986) 'Strategic Factor Markets: Expectations, Luck, and Business Strategy', Management Science 32 (10): 1231-1241.

Bitler, M.P., Moskowitz, T.J. and Vissing-Jørgensen, A. (2006) 'Why Do Entrepreneurs Hold Large Ownership Shares? Testing Agency Theory Using Entrepreneur Effort and Wealth', working paper, http://papers.ssrn.com/sol3/papers.cfm?abstract_id=352480, January.

\footnotetext{
${ }^{5}$ High cognitive cost is due to the investor's lack of understanding of the entrepreneur's specific mindset and to the learning effort necessary to gain access to the entrepreneur's perception of strategic opportunity.

${ }^{6}$ Cognitive value may only be derived from certain investors' specific expertise and know-how which would enhance a venture's managerial capabilities and/or strategic perspective.
} 
Busenitz, L. and Barney, J. (1997) 'Differences between Entrepreneurs and Managers in Large Organizations: Biases and Heuristics in Strategic Decision Making', Journal of Business Venturing, 12: 9-30.

Charreaux, G. (2002) 'L'actionnaire comme apporteur de ressources cognitives', Revue Française de Gestion 28 (141), November-December, Special Issue: 77-107.

Conner, K.R. and Prahalad, C.K. (1996) 'A Resource-based Theory of the Firm: Knowledge Versus Opportunism', Organization Science 7 (5), September-October: 477-501.

Cumming, D. and Johan, S. (2007) 'Advice and Monitoring in Venture Finance', Financial Markets Portfolio Management, 21: 3-43.

Forbes, D. (1999), 'Cognitive Approaches to New Venture Creation', International Journal of Management Review, 1: 415-439.

Forbes, D. \& Milliken, F. (1999), 'Cognition and Corporate Governance: Understanding Boards of Directors as Strategic Decision Making Groups', Academy of Management Review, 24 (3): 489-505.

Fransman, M. (1994) 'Information, Knowledge, Vision and Theories of the Firm', Industrial and Corporate Change 3 (3): 713-757.

Gompers, P., Kovner, A., Lerner, J. and Scharfstein, D. (2006) 'Skill vs. Luck in Entrepreneurship and Venture Capital: Evidence from Serial Entrepreneurs', working paper, Harvard University, July.

Hambrick D.C., Cho T.S. et M. Chen (1996), «The Influence of Top Management Heterogeneity on Firm's Competitive Moves », Administrative Science Quarterly, vol. 41, $\mathrm{n}^{\circ} 4$, p. 659-684.

Hambrick, D.C. and Mason, P.A. (1984), 'Upper Echelons : the Organization as a Reflection of Its Top Managers', Academy of Management Review, 9: 193-206.

Hellmann, T. and Puri, M. (2002) 'Venture Capital and the Professionalization of Start-Up Firms: Empirical Evidence', Journal of Finance LVII (1): 169-197.

Huff, A. (1990), Mapping Strategic Thought, Wiley.

Jensen, M. (1993) 'The Modern Industrial Revolution, Exit, and the Failure of Internal Control Systems', Journal of Finance 48 (3): 831-880.

Jensen, M. and Meckling, W. (1976) 'Theory of the Firm: Managerial Behavior, Agency Costs, and Ownership Structure', Journal of Financial Economics 3: 78-133.

Krueger, N. (2003), 'The Cognitive Psychology of Entrepreneurship', in Z. Acs and D. Audretsch, eds., Handbook of Entrepreneurship Research, Kluwer: 105-140. 
Murneiks, C., Haynie, J., Wiltbank, R. and Harting, T. (2007), 'I Like how You Think: The Role of Cognitive Similarity as a Decision Bias', paper presented at the Academy of Management Annual Meeting, Best Empirical Paper Award, Philadelphia, PA.

Nelson, R.R. and Winter, S.G. (1982) An Evolutionary Theory of Economic Change. Cambridge: Harvard University Press.

Nonaka, I., Toyama, R. and Byosière, P. (2001), 'A Theory of Organizational Knowledge Creation: Understanding the Dynamic Process of Creating Knowledge', in M. Dierkes, A. Berthoin-Antal, J. Child and I. Nonaka, Handbook of Organizational Learning and Knowledge, Oxford University Press, 491-517.

Penrose, E. G. (1959) The Theory of the Growth of the Firm. Oxford: Blackwell.

Roe, M. (2002), 'Corporate Law's Limits', Journal of Legal Studies, 31.

Rosenstein, J., Bruno, A., Bygrave, W. and Taylor, N. (1993) 'The CEO, Venture Capitalists, and the Board', Journal of Business Venturing 8: 99-113.

Teece, D. J., Pisano, G. and Shuen, A. (1997) 'Dynamic Capabilities and Strategic Management', Strategic Management Journal 18 (7): 509-533.

Walsh, J. (1995), 'Managerial and Organizational Cognition: Notes from a Trip Down Memory Lane', Organization Science, 6: 280-321.

Wernerfelt, B. (1984) 'A Resource-Based View of the Firm', Strategic Management Journal 5: $171-180$.

Witt, U. (1998), 'Imagination and Leadership: The Neglected Dimension of an Evolutionary Theory of the Firm', Journal of Economic Behavior \& Organization, 35: 161-177. 